\title{
Methodological sensitivities for co-producing knowledge through enduring trustful partnerships
}

\author{
Alison Greenaway ${ }^{1}$ D $\cdot$ Holden Hohaia ${ }^{2}$. Erena Le Heron ${ }^{3} \cdot$ Richard Le Heron $^{4} \cdot$ Andrea Grant $^{5} \cdot$ Gradon Diprose $^{6}$. \\ Nicholas Kirk ${ }^{7} \cdot$ Will Allen ${ }^{8}$
}

Received: 12 February 2021 / Accepted: 20 October 2021 / Published online: 19 November 2021

(c) The Author(s) 2021

\begin{abstract}
Indigenous ways of caring for the environment have long been marginalised through research methodologies that are blind to a range of ways of knowing the world. Co-production of knowledge across Indigenous knowledge systems and Western scientific approaches is receiving attention both internationally and within the science system in Aotearoa New Zealand. Addressing power asymmetries as part of the co-production process is also slowly gaining recognition. Those involved in knowledge co-production initiatives must support learning about different world views, ways of knowing and accounting for the environment, while also enabling learning of the many biases and assumptions built into methodologies. This deliberation is needed, so non-Indigenous researchers can form enduring trustworthy partnerships and contribute to co-production initiatives. Presented here are insights shared by a cohort of environment research practitioners who have been deliberating on co-production occurring across knowledge systems in Aotearoa New Zealand. Originating from analysis of interviews undertaken about relationships recreational groups have with Te Urewera (forested hill country in the North Island of Aotearoa New Zealand), this paper depicts a layered reflection on how non-Māori (primarily but not exclusively) across Aotearoa New Zealand are learning to be manuhiri (those being welcomed on arrival to a place by the Indigenous people of that place). As a contribution to this collective learning, a set of methodological sensitivities are proposed as support for research amidst changing relationships with places. Doing so we aim to contribute to reflexive and decolonising encounters with Indigenous approaches to environmental care.
\end{abstract}

Keywords Non-Indigenous $\cdot$ Manuhiri $\cdot$ Knowledge $\cdot$ Co-production $\cdot$ Environment $\cdot$ Conservation

Handled by Clemens Grünbühel, Stockholm Environment Institute Asia, Thailand.

Alison Greenaway

greenawaya@landcareresearch.co.nz

1 Manaaki Whenua-Landcare Research, Private Bag 92170, Auckland, New Zealand

2 Ngāti Maru/Taranaki Whānui ki te Ūpoko o te Ika, Manaaki Whenua-Landcare Research, The Terrace, PO Box 10345, Wellington, New Zealand

3 Le Heron Leigh Consulting Limited, Auckland, New Zealand

4 School of Environment, University of Auckland, Private Bag 92019, Auckland, New Zealand
5 SCION Research Ltd., Riccarton, PO Box 29237, Christchurch, New Zealand

6 Manaaki Whenua-Landcare Research, The Terrace, PO Box 10345, Wellington, New Zealand

7 Manaaki Whenua-Landcare Research, 54 Gerald Street, Lincoln, New Zealand

8 Learning for Sustainability, Barrington, PO Box 30108, Christchurch, New Zealand 


\section{Introduction: addressing power asymmetries across knowledge systems}

The well-being of a significant share of the planet depends on the institutions and actions of Indigenous peoples who are connected to over a quarter of the world's land surface (Garnett et al. 2018). Indigenous approaches to and systems of sustainability and science are diverse reflecting the diverse land/water/seascapes they connect with (Johnson et al. 2016). Yet Indigenous knowledge systems remain constrained by environmental research funding agendas dominated by Western methodologies and frameworks. Research showing how power and agency are assembled through knowledge production and implementation processes frequently highlight the need for more pluralistic approaches to environmental care. Colonisation still occurs through many conservation, resource management and ecosystem services initiatives (de Sousa Santos 2008; Shiva 2001; Athayde et al. 2017; Chilisa 2017). While the Intergovernmental Platform for Biodiversity and Ecosystem Services (IPBES) actively works to include Indigenous knowledges, Hill et al. (2020:17) note, "power asymmetries remain a formidable barrier to working across knowledge systems in IPBES and other environmental assessments". This paper responds to this challenge by (a) working with a relational framing (manuhiri) offered by Māori (Indigenous peoples) in Aotearoa New Zealand; (b) focusing on the learning this framing provoked for social research entangled with Western science attempting to co-produce sustainable development; and (c) providing a set of methodological sensitivities to support further deliberation about partnerships for sustainability science.

The term manuhiri (visitors or guests) is used in this paper with reference to those who come as guests or visitors to Te Urewera and in doing so arrive in the place where Ngāi Tūhoe iwi ${ }^{1}$ are an Indigenous people. Typically, across Aotearoa New Zealand, manuhiri is translated into English as guests and visitors with reference to the values and etiquette associated with arrival at a marae (gathering space) or new place (Mead 2016; Rata et al. 2012). Manuhiri conveys an encounter and relationship with tangata whenua ${ }^{2}$ (the Indigenous people of a specific area) through invitation and shared responsibility (Mikaere, 2011 pp. 111-113). Being

\footnotetext{
1 Iwi are an extended kinship group, tribe, nation, people, nationality, race-often refers to a large group of people descended from a common ancestor and associated with a distinct territory (maoridictionary.co.nz).

2 Tangata whenua are the local people, hosts, indigenous peoplepeople born of the whenua, i.e. of the placenta and of the land where the people's ancestors have lived and where their placenta are buried (maoridictionary.co.nz). Ngāi Tūhoe are tanata whenua of Te Urewera, in their dialect the $\mathrm{g}$ is dropped.
}

manuhiri is a practice and identity which is part of being Māori and being Pākehā (non-Māori New Zealanders with a British settler background ${ }^{3}$ ) and being Tauiwi (all those in Aotearoa New Zealand who are not Indigenous). It is also an important positionality adopted by kaupapa Māori researchers (Māori researchers working with a Māori philosophical doctrine) (Rata et al. 2012). The term is used in this paper as gifted in Te Kawa o Te Urewera ${ }^{4}$ (Te Uru Taumatua 2017) and alternatives are provided which arose in conversations moving away from Te Urewera, such as kaimanaaki (those who provide care); tangata tiriti (the people of te Tiriti o Waitangi ${ }^{5}$ who are in relationship with tangata whenua); allies (people who actively support Indigenous interests).

We use the relational frame of manuhiri to explore the adoption of justice-based approaches to co-producing knowledge and practices for environmental care in partnership with Indigenous peoples (Allen et al. 2009; Hikuroa et al. 2011; Reo et al. 2017; Latulippe and Klenk 2020; Parsons et al 2021). Co-produced knowledge must include a focus on unsettling the research and management ethics and practices which fragment knowledge of nature and society and disconnect people from environments (Moewaka Barnes et al. 2021; Latulippe and Klenk 2020; Elkington et al. 2020; Howitt 2020).

Co-produced knowledge and practice offers much hope for degraded environments in Aotearoa New Zealand (Ruru et al. 2017). For example, after exploring complementary approaches for monitoring of a section of forest in Te Urewera Lyver et al. (2018:1921) found the co-production of knowledge (across Western scientific and Indigenous Māori monitoring systems) has the potential to "inform different sections of society about attributes of ecosystems relevant to them, and if appropriately aligned, could inform each other and offer a dual process for application that can reveal more than either can individually". To take up this opportunity, research is becoming sensitised to te ao Māori ${ }^{6}$ and developing more reflexive agility for working across knowledge systems.

In the section below, we outline the context of co-management in Aotearoa New Zealand which is providing impetus for co-produced environmental knowledge and practice. It is in this context that environment and recreation groups

\footnotetext{
${ }^{3}$ See Forsyth (2018) for further discussion of this identity and its ongoing development.

${ }^{4}$ Te Kawa o Te Urewera-a seminal publication outlining a unique vision for the management of Te Urewera.

5 Te Tiriti o Waitangi/ the Treaty of Waitangi is one of Aotearoa New Zealand's founding documents, establishing rights, responsibilities, and relationships between the Crown and tangata whenua. It takes its name from the place in the Bay of Islands where it was first signed, on 6 February 1840.

${ }^{6}$ Te ao Māori-the way of perceiving and understanding the world, and the values and systems of thought that underpin those perceptions.
} 
(and their research collaborators) are learning to be manuhiri (to arrive appropriately in relationship with Indigenous peoples). The material and methods section presents the approach noting this paper narrates the series of conversations through which data were collected, co-analysed and which supported deliberation about knowledge co-production methodologies. The results are presented as a tracing of these conversations out of Te Urewera, to Wellington, and then as online deliberations. In the discussion, a table is provided offering the reader a prompt for their own discussions about methodologies and the sensitivities which support enduring trustworthy partnerships for Indigenous cultural and environmental management. The paper concludes by assessing how our work with the relational frame of manuhiri supports knowledge co-production and identifies further questions and opportunities for this work.

\section{Context and background: collaborative environmental care in Aotearoa New Zealand}

Environment and recreation groups in Aotearoa New Zealand are navigating a shift from linear, siloed environmental management to collective management. As co-management of $\left(\right.$ and with ${ }^{7}$ ) places becomes more typical, community groups (e.g. tramping, pest control, and mountain biking) find they are changing how they relate with places, tangata whenua, and crown agencies involved with these places. In some parts of Aotearoa New Zealand, this is a journey of learning to be manuhiri. Co-management of places is being enabled through Te Tiriti o Waitangi settlements establishing co-governance agreements; the Resource Management Act (1991); related memorandums of understanding; or special legislation supporting collaborative decision-making driven by tangata whenua (Harmsworth et al. 2016; Timoti et al. 2017; Maxwell et al. 2020; Parsons and Fisher 2020). Behind all these initiatives is a raft of workstreams which have gathered capacities for more relational ways of caring for the environment and generated momentum for coproduced environmental and cultural practices.

In 2013, Harmsworth and Awatere presented a planning framework based on the principles of Te Tiriti o Waitangi (page 282). This framework provides a relational presentation showing how to frame thinking and practices for environmental decision-making in Aotearoa New Zealand. We note that not all iwi signed the Te Tiriti o Waitangi and

\footnotetext{
$\overline{7}$ See Hill et al. (2020) for an example of learning and managing with a river.
}

this framing is not designed as a one-size-fits-all. ${ }^{8}$ In 2015 , Robb et al. found that while there was increased talk about co-management, co-governance, and co-planning, it was not clear how these differed in practice. To support more clarity, they provided a conceptual model based on te ao Māori ${ }^{9}$ perspectives that shows co-governance, co-management, and co-planning as essential phases of collaboration to protect and sustain freshwater in Aotearoa New Zealand.

Table 1 below extends previous work ${ }^{10}$ by the authors and their colleagues about co-governance, co-management and co-planning (Robb et al. 2015; Taylor et al. 2018; Parsons and Fisher 2020). This table ${ }^{11}$ points to a diversity of arrangements being used (with varying qualities of partnership). Our review criterion was to illustrate a diversity of ways the wider community or manuhiri have responded to these arrangements.

Looking ahead, the 2020 amendment to the National Policy Statement for Freshwater Management (MfE 2020) now instructs all local authorities to actively involve tangata whenua (to the extent they wish to be involved) in freshwater management (including decision-making processes), including all of the following:

a. identifying the local approach to giving effect to Te Mana o te Wai ${ }^{12}$

b. making or changing regional policy statements and regional and district plans so far as they related to freshwater management

c. implementing the National Objectives Framework, and

d. developing and implementing Māori knowledge systems and other monitoring.

\footnotetext{
${ }^{8}$ Māori scholars argue that Te Tiriti o Waitangi applies to all partnerships between the Crown and tangata whenua regardless of whether a specific leader signed. Those who argue that a Treaty framing isn't particularly useful advocate for mana motuhake (self-determination) and the declaration of independence which preceded $\mathrm{Te}$ Tiriti o Waitangi.

${ }^{9}$ Te ao Māori-the way of perceiving and understanding the world, and the values and systems of thought that underpin those perceptions.

${ }^{10}$ See Le Heron et al. (2019)

11 Table 1 does not provide an exhaustive list of current co-management and co-governance approaches nor does it fully represent the diversity of ways people have responded in each locality. For a more exhaustive overview of co-governance in Aotearoa New Zealand refer to https://oag.parliament.nz/2016/co-governance/docs/co-governanceamended.pdf

12 Te mana o te wai-refers to the vital importance of water and recognises that protecting the health of freshwater protects the health and well-being of the wider environment (including people). This principle guides the framework for the National Policy Statement for Freshwater Management 2020.
} 


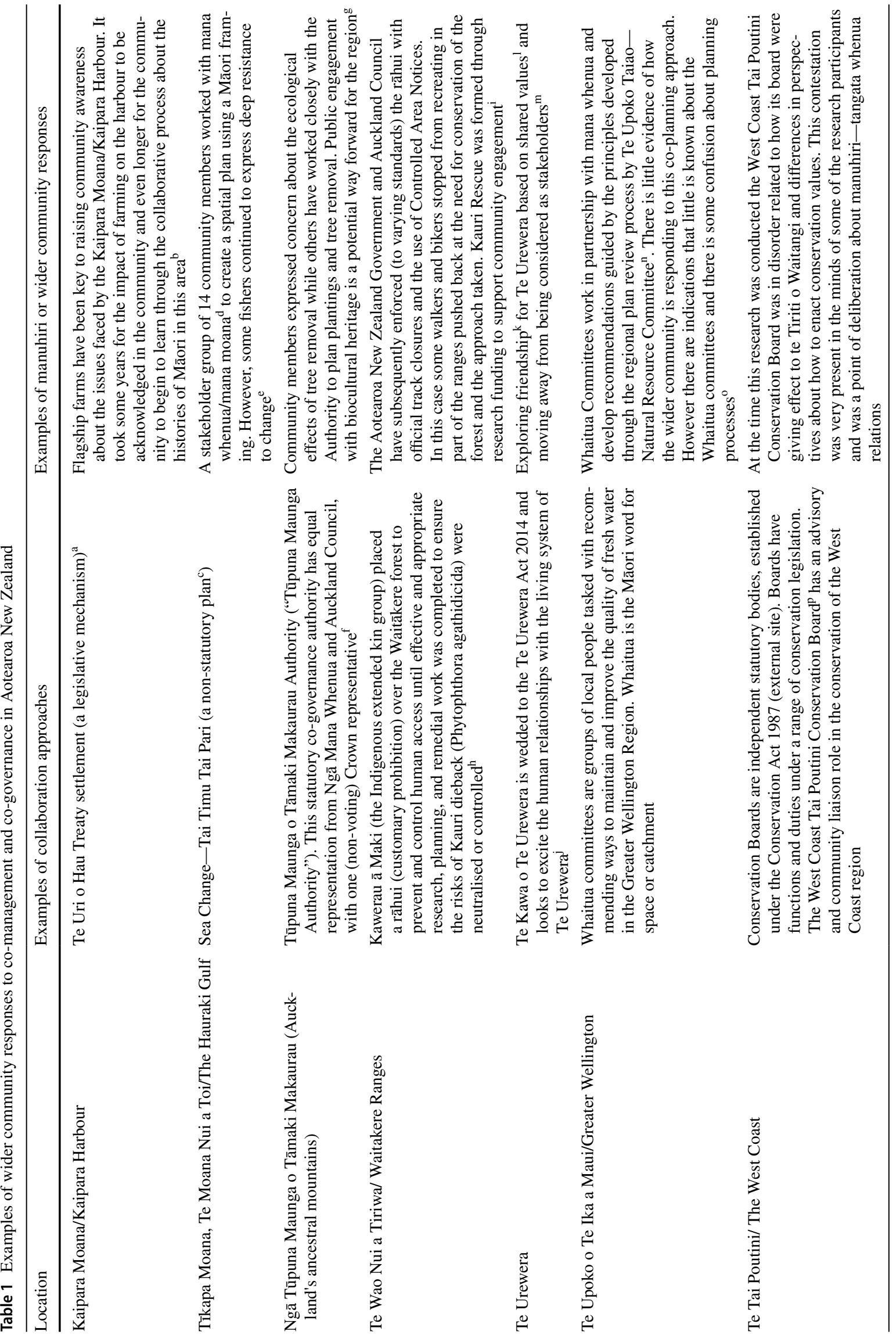




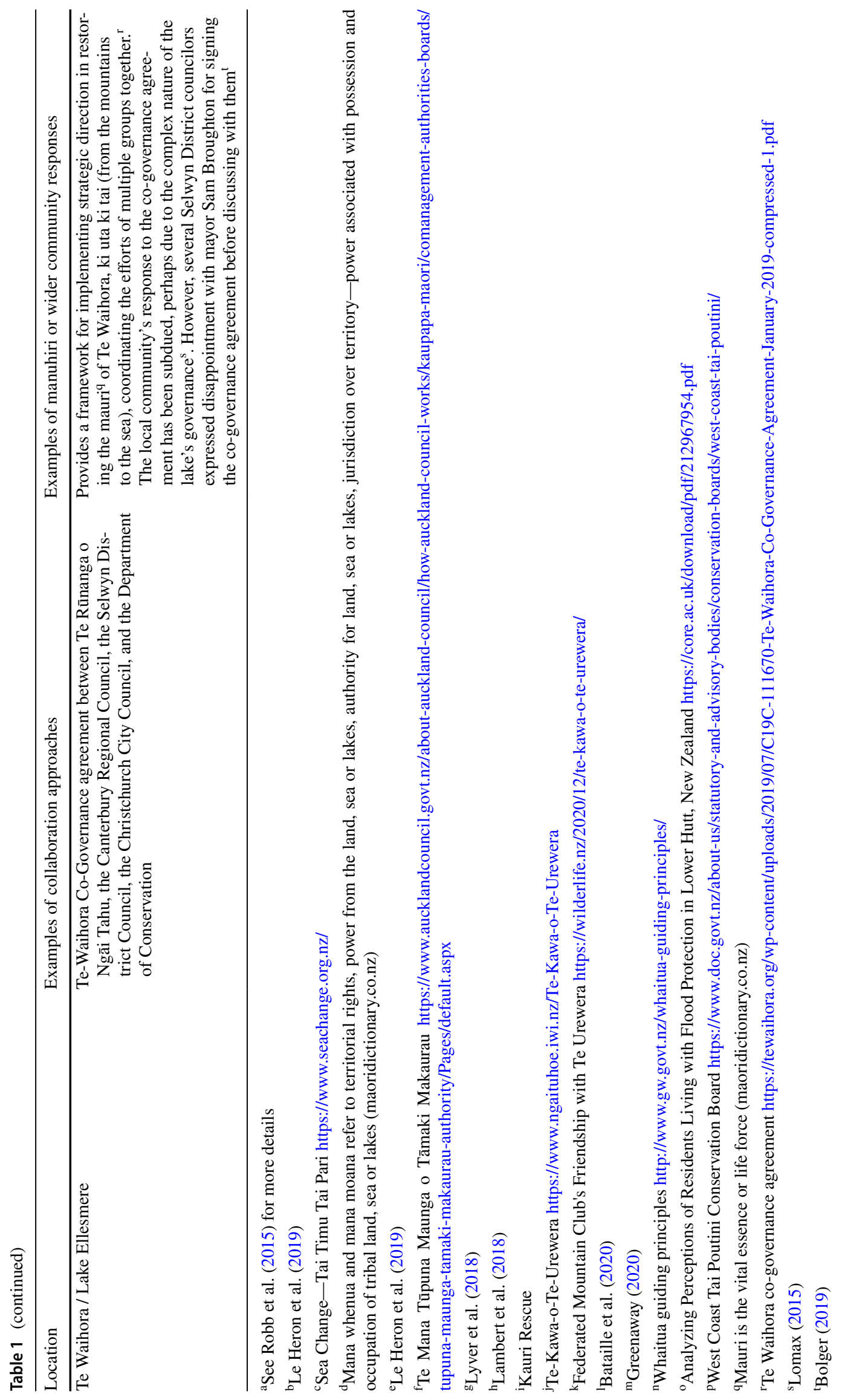


Many recreation and environment groups are associated with the vast number of rivers and other bodies of water shaping Aotearoa New Zealand. Creation of the National Policy Statement for Freshwater Management presents a significant moment in relations between Māori and non-Māori (tangata whenua and tangata tiriti) for which methodological sensitivity will be critical.

This paper was written at a time when institutional racism was getting more attention in Aotearoa New Zealand and internationally. As this paper was developed, the teaching of Aotearoa New Zealand history was established as part of the education curriculum ${ }^{13}$ (New Zealand Government 2021); there was an apology from a major media outlet about their racial bias ${ }^{14}$ (Stevens 2020); racism in the academic editorial process was in the spotlight (Selak et al. 2020); a civics education web series was released teaching Aotearoa New Zealand history and how it shapes society today; conference sessions on related topics, and several informative public and academic publications (Came-Friar et al. 2019; McAlister et al. 2020). It was in this milieu that funding was secured, mandating and enabling investment of time and scholarship in this topic. Included in this paper are published opinion pieces, illustrating the growing public narrative surrounding and informing this work. ${ }^{15}$

As sustainability science has developed over the last decade so has the distinctive field of Indigenous research. ${ }^{16}$ Environment oriented transdisciplinary research is growing a cohort of research practitioners who are at least familiar with if not fully engaged with decolonising methodologies (King et al. 2008; Johnson et al. 2016; Zanotti and Palomino-Schalscha, 2016; Seehawer 2018; Chitondo and Dombroski 2019; Maclean et al 2021). While this shift occurs, science-policy communities of practice are seeing the need to increase reflexive capabilities to address power imbalances shaping these initiatives (through funding priorities, intersecting policy agendas, colonial legacies, etc.). To support these reflexive capabilities, this paper explores what happens when a relational frame (manuhiri) becomes the focus of inquiry and reflection; what possibilities for the co-production ${ }^{17}$ of environmental knowledge and practices are generated?

\footnotetext{
13 Teaching NZ's own history moves a step closer. https://www.beehive. govt.nz/release/teaching-nz's-own-history-moves-step-closer.

${ }^{14}$ Stuff's apology to Māori-Our Truth, Tā Mātou Pono. https:// www.stuff.co.nz/pou-tiaki/our-truth/300165985/our-truth-t-mtoupono-stuffs-day-of-reckoning.

15 For further discussion on how narratives are shaping Aotearoa New Zealand see Le Heron et al. (2020a, b).

16 In 2020 Indigenous Research in Australia and New Zealand gained its own academic publishing classification. (ARC 2020).

17 For a deep dive into co-production approaches and complexities see Zurba et al. (2021) in this Special Feature.
}

\section{Materials and methods}

Invitations, gifts, and collaborative navigation were both the focus of this inquiry as well as the mode of inquiry. By giving attention to these social processes, we provide an approach which guides towards the enduring partnerships this paper aims to contribute to.

Whilst all the authors have shared insights with at least the lead author, this paper is not an output from group analysis and nor does it offer consensus agreement. Instead, this paper documents threads of reflection and inquiry across the authors. The text predominantly communicates the Pākehā lead author's perspectives and how these have developed in relationship to the contributions, provocations and reflections of the other authors and reviewers (some of whom are Māori). This style of writing is an attempt to make more visible the relationships and practices which support co-learning.

Vital to these interchanges is an understanding of methodology as theory in practice, creating worlds (Carolan 2009). Co-produced knowledge opens alternative worlds and develops new social contracts (Norström et al. 2020; Duncan et al. 2018; Allen et al. 2009; Jasanoff 2004). The social knowledge presented here is generated and gifted through relationships of people embodied with nature in specific places, and not a detached static description which can be generalised without recognition of the context it is generated from. Hence, with an ethic of reciprocity ${ }^{18}$ we build off contributions from Indigenous scholars, kairangahau Māori ${ }^{19}$ colleagues and those intentionally creating spaces (in organisations, budgets and funding processes, review practices, etc.) for Indigenous knowledge and practices.

Responding to invitations to engage with Indigenous knowledge systems and approaches to sustainability, the interviews, workshops and writing shifted the gaze ${ }^{20}$ of inquiry and action to non-Indigenous knowledges, cultures, and relationships with nature. While emphasising the contextual specificity of this paper, we do not diminish the opportunity it provides for researchers in other contexts to develop the methodological sensitivities we outline. These sensitivities represent choices made and dispositions taken that are highly relevant to co-producing sustainability, and indeed help to prepare for knowledge co-production encounters.

\footnotetext{
${ }^{18}$ We note this ethic is central to much of the research outlined in the Special Issue this paper contributes to. It is also a core value underpinning Te Ara Tika Guidelines for Māori research ethics: A framework for researchers and ethics committee members.

19 Māori researchers.

20 This is a critical step in reframing positionality as shown through the work of Borrell et al. (2019); Smith (1999); Said (1978) and many other advocates of decolonisation and postcolonialism.
} 
The analysis was developed through reflexive inquiry (Apgar et al. 2017) and critical contextual analysis informed by interviews with manuhiri groups of Te Urewera $(N=14)$, workshops about being manuhiri (including a Lake Waikaremoana Summit, a workshop with environment and recreation groups in Wellington and group discussions with research colleagues and the authors) $(N=4)$, document, and media review. Social Ethics approval (application 2021/18 NK) was received through Manaaki Whenua-Landcare Research (a Crown Research Institute).

Section 3 narrates an unfolding of insights developed and shared through research relationships. An account of learning to be manuhiri is made drawing from interviews (undertaken by Alison) and observations from the Summit (facilitated by Holden), October 2019-February 2020. Then, the paper shows how this conversation about being manuhiri travelled away from Te Urewera to a workshop held in December 2020, in Wellington Aotearoa New Zealand. This was facilitated by Alison and Holden and designed with one other participant from the Lake Waikaremoana Summit plus another leader of a Te Urewera manuhiri group. Leaders from six environment and recreation focused organisations participated, plus two research leaders.

The third undertaking pivoted the gaze of inquiry towards the science system in which this work was situated. Alison and Holden supported collegial deliberations across research projects ${ }^{21}$ with which the authors of this paper have been involved over the last five years. This process of co-analysis was supported by the circulation of a discussion paper, a workshop (facilitated by Alison) exploring resources for building capacity to support Crown-Māori relations in Aotearoa New Zealand public service, ${ }^{22}$ informal 1:1 and group conversations (lead by Alison), as well as through the writing and review of this paper. Participants were invited on the basis that they were leaders of environment and recreation groups, or environmental researchers; had a relationship with Māori advisers; and had a willingness to reflect, critique and learn.

The analogy of the waka taurua (two connected boats navigating together) was shared by colleagues (Maxwell et al. 2020) through the Sustainable Seas National Science Challenge, and the waka hourua (a twin-hulled sailing vessel) is a guiding signifier for the Mobilising for Action programme of work in the Biological Heritage National Science Challenge, which funded the writing of this paper. It is a powerful signifier of the deep knowledge produced through

\footnotetext{
${ }^{21}$ Enabling EBM Narratives, Sustainable Seas; Participatory processes, Sustainable Seas; Biological Economies; Postcolonial Biosecurity Possibilities, Biological Heritage Challenge; Primary Industry Advisory Services; Toolkit for the urban battlefields; Ministry for Primary Industries urgent response to myrtle rust; Predator Free NZ.

${ }^{22}$ Te Arawhiti-Crown Māori relations. https://www.tearawhiti.govt.nz/.
}

centuries of Pacific navigating which is a foundation for mātauranga ${ }^{23}$ and a gift to Western science shared through Te Tiriti o Waitangi (Rata et al. 2012). It is also a pivotal organising symbol for Te Mana Rauhī Taiao-Environmental Protection Authority in Aotearoa New Zealand. ${ }^{24}$

We are paying attention to where the wood for the tauiwi (non-Māori) side of the waka has come from, and how it is being crafted (e.g. the influence of our disciplines, epistemologies and our funding, accountability processes). One point of consideration has been the question 'for kaupapa Māori research to thrive, do other research approaches need to be left behind?' This remains an open and productive question. The following findings are from the interviews, workshops and collegial discussions about being manuhiri. This section traces a 'collective conversation' beginning with the challenge and invitation from Te Urewera to become manuhiri, the discomfort and hope generated through this invitation; then the extension of this conversation and how this again forced engagement with a plurality of world views and institutional dynamics. Overall relationship building and relational ways of thinking, and working were deemed top priority for co-producing sustainable development outcomes and this is assisted when connections are made across shared values.

\section{Results}

Two significant findings emerged from this work:

- Learning to be manuhiri (to be welcomed as new arrivals to a place with a responsibility to care for that place) is providing an opportunity to contribute to collective care for and with nature in Aotearoa New Zealand.

- Methodological sensitivities can steer away from colonising knowledge-practice approaches towards co-production across knowledge systems.

Legal recognition of the rights of nature ${ }^{25}$ forces people to think in new ways, opening new possibilities for how

\footnotetext{
${ }^{23}$ Māori knowledge — the body of knowledge originating from Māori ancestors, including the Māori world view and perspectives, Māori creativity and cultural practices (maoridictionary.co.nz). When this paper was reviewed it was suggested the authors engage with debates about use of Mātauranga vs Mātauranga Māori. Aiming to avoid reinscribing another dualism we use mātauranga, with the exception of where we refer to how other organisations use of this term.

${ }^{24}$ Mātauranga Māori and the EPA. https://epa.govt.nz/communityinvolvement/science-corner/matauranga-maori/.

25 Since 2006, governments around the world have adopted legal provisions recognising Nature as a subject with inalienable rights. Legal provisions now exist in Bolivia, Brazil, Colombia, Ecuador, India, Mexico, New Zealand, Norway, and the United States (see Magallanes (2015) for elaboration).
} 
manaaki whenua or care for the land might be understood, represented, enacted, and researched, both in and beyond Aotearoa New Zealand. Legal personification reshapes our relationships with places, rebuilds esteem and invites the legal persona to speak (Geddis and Ruru 2019).

Te Urewera is a remote, rugged area of hill country in the North Island and is the homeland of Ngāi Tūhoe. From 1954 until 2014, much of Te Urewera was designated by the Crown as a National Park, managed through the Department of Conservation. The Te Urewera Act 2014, established Te Urewera as an independent legal identity in perpetuity, designating protected status for Te Urewera for its intrinsic worth, its distinctive natural and cultural values, the integrity of those values, and its national importance (see Jones 2014).

The new Act sought to strengthen and maintain the connection between Ngāi Tūhoe and Te Urewera; to preserve as far as possible the natural features and beauty of Te Urewera, the integrity of its indigenous ecological systems and biodiversity, and its historical and cultural heritage; and to provide for Te Urewera as a place for public use and enjoyment, for recreation, learning, and spiritual reflection, and as an inspiration for all (Te Uru Taumatua 2017).

Published in 2017, the landmark document Te Kawa o Te Urewera articulates the principles that govern Te Urewera, the roles, relationships, and responsibilities people (and crown organisations like the Department of Conservation) play in its care, and the place of Ngāi Tūhoe and manuhiri in relation to Te Urewera (Te Uru Taumatua 2017). Ngāi Tūhoe and the Department of Conservation are using Te Kawa to set annual priorities, plan, and develop formal friendship relationships with groups to care for (and with) Te Urewera. An ethos permeating Te Kawa o Te Urewera is "the management of people for the benefit of the land-it is not about land management" (Te Uru Taumatua 2017). Te Urewera provides a powerful challenge to sustainability science practitioners in that Ngāi Tūhoe have tasked themselves with accounting for the values of non-Tūhoe (the manuhiri), whilst still addressing the values and inequity of colonialization from the past 175 years for their own people (Te Uru Taumatua 2017).

In September 2019, Holden Hohaia and Alison Greenaway were asked by Te Uru Taumatua, Ngāi Tūhoe iwi, ${ }^{26}$ to support them in preparation for a second Te Urewera Summit with manuhiri (the first was in $2012^{27}$ ). Members of

\footnotetext{
${ }^{26}$ Te Uru Taumatua is a governing body which leads and serves the cultural permanency and prosperity of Ngāi Tūhoe.

27 See Bataille et al. (2020) for a rich description of this 2012 process. The first Summit was held in 2012 where the expression of friendship for Te Urewera was shared by Ngai Tūhoe iwi.
}

14 manuhiri groups ${ }^{28}$ were interviewed by Alison to review how their friendships with Ngāi Tūhoe for Te Urewera have grown since 2012 (Greenaway 2020). The Summit held on the shores of Lake Waikaremoana was held in January 2020, facilitated by Holden, and attended by 40 people from the manuhiri groups, Te Urewera board members, and members of a Department of Conservation appointed review panel. Discussion was wide-ranging including how the manuhiri as friends of Te Urewera might work more collectively together with Ngāi Tūhoe.

Earlier that year, media coverage had reported Ngāi Tūhoe concerns about the dumping of waste and other disrespectful behaviours by campers and boat users in and around Lake Waikaremoana. Stories were also published in local news outlets of visitor concerns about the upkeep of walking tracks, maintenance of huts, and rubbish collection around the lake. ${ }^{29}$

Through the interviews with manuhiri groups, Alison heard how they had cared for Te Urewera in the past and their aspirations for the future. Many of the groups had stories of their grandparents and great-grandparents building tracks and huts or putting in jetties. Alison also frequently heard about how things changed after the collapse of the Cave Creek viewing platform and the related changes to the Health and Safety at Work Act (2015) and resulting reduction of volunteer contributions. ${ }^{30}$ Changes to health and safety legislation were presented by many of the interviewees as a more significant legislative change affecting the groups' relationships with Te Urewera than the 2014 Te Urewera Act.

When manuhiri were asked about their concerns for $\mathrm{Te}$ Urewera, the Department of Conservation (DOC) was still very much a focal point. There were questions about how well DOC were supporting Ngāi Tūhoe, the disappearance of DOC altogether from the area, that management of the area was either too much or too little like what DOC used to do. Also central to concerns were the quality and strength of relationships, and how to build and maintain relationships with both DOC and Ngāi Tūhoe. Some manuhiri voiced concerns about either Ngāi Tūhoe or other visitor activities through the media, as shown by the headlines in local papers mentioned above.

At the 2020 Lake Waikaremoana summit, a commitment was expressed that the manuhiri groups would try to work together as friends of Te Urewera. Previously, most groups

\footnotetext{
$\overline{28}$ The groups interviewed and invited to workshops are not named here, respecting the tentativeness by which people come to this conversation and their wariness to speak publicly about their learning at this stage, when there is still so much work to do to foster enduring and trustworthy partnerships.

${ }^{29}$ Rubbish at Lake Waikaremoana. https://www.stuff.co.nz/envir onment/110297191/calls-for-tougher-restrictions-at-lake-waikaremoa na-after-vandalism-and-rubbish-dumped-by-visitors.

${ }^{30}$ For more detail on this incident and its effects see Brookes (2018)
} 
had an individual relationship with the place, and a direct relationship with DOC. The groups were now fostering a more engaged relationship with Ngāi Tūhoe, as the first points of contact, the pivotal relationship in Te Urewera. It was noted, much of the pressure of communication Ngāi Tūhoe iwi were facing could be shared if the groups proactively worked together and became more aware of the contributions each group was making. Alison left the summit considering what role the larger organisations might play helping the groups as they all learned to be manuhiri.

\section{A plurality of world views}

A 'Learning to be manuhiri' workshop was held in December 2020 in Wellington (hosted by Holden and Alison) with 6 leaders of recreation and environment groups, two have a manuhiri friendship with Ngāi Tūhoe. The focus of the workshop ${ }^{31}$ was

1) co-learning about te Tiriti o Waitangi lead co-governance approaches for organisations

2) leadership for non-Māori involved in places co-managed with iwi and hapu $\bar{u}^{32}$

3) developing resources to support learning to be manuhiri, tangata tiriti and/or kaimanaaki ${ }^{33}$

When developing the purpose for this workshop, terms similar to manuhiri were added because the relational identity expressed through Te Kawa o Te Urewera differs in other places in Aotearoa New Zealand. Some groups have been gifted the term kaimanaaki by tangata whenua to identify them as the people who take care of a place. Others refer to themselves as tangata tiriti to show they see themselves in partnership with tangata whenua through te Tiriti o Waitangi. Others use the term allies as a more international term for those supporting the interests of Indigenous peoples (see Huygens 2016 and Kluttz et al. 2020 for further elaboration and critique of these identities).

Before and during the workshop, these leaders of environment and recreation groups expressed a tentativeness about this topic, aware they were only at the very start of a learning journey and there was far to travel. This humility and openness to learning provided a strong foundation for honest, exploratory conversations in the workshop. An etiquette of

\footnotetext{
31 Funded through the Biological Heritage National Science Challenge.

${ }^{32}$ Hapū are a kinship group, clan, tribe, subtribe - section of a large kinship group and the primary political unit in traditional Māori society (maoridictionary.co.nz).

33 Which can now be found at www.landcareresearch.co.nz/beingmanuhiri
}

active listening, constructive feedback, and careful disclosure post the workshop was also established.

During the workshop the group discussed how they were learning to recognise other world views and were developing a growing appreciation for te ao Māori (a Māori world view). This required educating oneself about historical injustices and their long-term impacts. ${ }^{34}$ Some realised they needed to learn more about colonial histories and colonising ways of knowing, to go beyond the dominant narratives which have for so long kept Māori experiences invisible in the public arena. This included greater understanding of the trauma Māori experienced through war, land confiscation, institutionalised racism, and disenfranchisement. It was noted that many Pākehā hold deep attachments to places and beliefs about their rights to undertake certain activities. ${ }^{35}$ For example, Pākehā who refuse to reconsider their sense of entitlement or right to use, own, and access land. When confronted about this sense of entitlement, many Pākehā required support to process and manage their grief without it becoming a burden for Māori partners.

The challenge of institutional support remained a hurdle, some of the groups struggled to gain a mandate via their boards to develop authentic relationships with Māori. A common challenge faced by these organisations was how best to communicate back to funders the importance and benefits of investing in partnerships with Māori organisations. Legislative changes requiring many organisations to 'give effect to' te Tiriti o Waitangi rather than 'take into account' te Tiriti (Ruru 2004) were creating more impetus. Additionally, those who had engaged with the science system had found it difficult to overcome some disciplinary protocols. Sometimes, the Aotearoa New Zealand science system was itself a barrier to genuine partnership with Māori (for further explanation see Ruru and Nikora 2021). This added to the underdevelopment of capacity and capability for Māori coming through education systems-which is particularly an issue in science (McAllister et al. 2020).

It was apparent through the interviews with manuhiri, as well as the Lake Waikaremoana Summit and Wellington workshop, that considerable discomfort is felt by individuals learning to be manuhiri. Anxieties about belonging, loss of rights, ways of identifying self and social groups, and senses of place were generated along with strong opinions about what effective conservation should involve. Sometimes, this led to tears of grief and moments of deep reflection, other times it led to defensiveness and contestation through letters

\footnotetext{
${ }^{34}$ Some participants found this article (https://e-tangata.co.nz/ comment-and-analysis/moving-from-tokenism-to-respect/) a useful prompt for their deliberations on being Pākehā.

${ }^{35}$ For a clear presentation of challenges many Pākehā express and ways to think through these see Becoming 'really Pākehā'-ETangata. https://e-tangata.co.nz/reflections/becoming-really-pakeha/.
} 
to government ministers or legal challenges in court. These expressions of contestation were also apparent in many of the locations noted in Table 1.

\section{Prioritising relationship building}

A strong sentiment expressed through both the interviews and the workshop was that relationships come first-and developing strong, caring and reciprocal relationships with iwi, hapū, and places is central to becoming Pākehā and learning to be manuhiri (when and where appropriate). Each leader expressed the need to prioritise and make time to build relationships. Having an existing relationship was particularly useful when needing to resolve controversial issues. It was also found that a focus on personal and societal well-being created opportunities to emphasise the benefits of human-nature connections. The well-being frame connected more readily to Māori worldviews.

Interviewees and workshop participants noted that it is helpful when they and their members do some reading and learning first before asking their Māori contacts directly. This might include, for instance, reviewing iwi management plans, reading publicly available information and reports (e.g. Waitangi Tribunal reports ${ }^{36}$ ), and thinking about how each organisation aligns with Māori aspirations. This, of course, required the organisation to become familiar with Māori aspirations. Increasing the number of Māori working for these organisations was one approach, but also aligning with similar Māori organisations was another. There is a potential for the burden of relationship building to be put onto Māori staff, rather than for it to be shared across the organisation. Either way it was found to be important to protect Māori colleagues and partners from unnecessary interruptions and requests (e.g. direct people to existing resources, advise them yourself, etc.). Partnering with Māori can provide an opportunity to reflect on Pākehā worldviews and this often requires strategies which prioritise relationships as an outcome or impact, thus building relationships into accountability metrics. When planning budgets, these groups needed to include funding to resource Māori partners, so they can be at the decision-making table.

To prioritise relationships, create institutional change, and engage with a plurality of world views, the participants saw the need for diverse stories which re-connect people to place. Telling stories helped show how environmental issues had arisen, and potential ways forward. Many of the research participants work with existing Pākehā attachments and values in their organisations to prompt new understandings and relationships. In the following discussion a table is provided

\footnotetext{
${ }^{36} \mathrm{https} / / /$ waitangitribunal.govt.nz/
}

which summarises the insights shared above and provides a further prompt for co-learning.

\section{Discussion: methodological sensitivities for co-producing sustainability}

This paper centres on a deepening knowledge of partnering. Continuous acts of interlocking and networking are key to the connecting required for the relational work of co-producing environmental knowledge. The insights documented in this paper show the learning required to authentically engage across knowledge systems in Aotearoa New Zealand. This paper also shows that learning is not just personal, undertaken by individual agency. It is also a collective endeavour, enabled through invitation, sharing of histories, glimpses across world views and intentional interventions to stop embedding colonising narratives of Indigenous peoples, local communities, the environment, and recreation. In Aotearoa New Zealand, there is a need (and in places a desire) for public conversations across multiple interests about conservation visions, priorities and mechanisms for collectively achieving these. ${ }^{37}$ Specific methodological sensitivities can orient research towards Indigenous peoples' world views and knowledge systems (Rout and Reid 2020). This is a call for critically reflexive approaches to co-producing revitalised relationships with nature.

In Aotearoa New Zealand, this is happening through the invitation to navigate with Māori colleagues a twin-hulled sailing vessel bringing mātauranga and other knowledges together through an interface that is developed as each waka moves in the same direction in relationship with the other (Maxwell et al 2020). Working with relational and shared values, such as care for the environment and situated representations of knowledge, may help if care is taken to recognise how these values are generated through a collective of human and non-human actors. This will mean revising practices of peer review, critique, and accountability so that processes enabling the development of Indigenous peoples' knowledge are invested in (e.g. Allen et al. 2014). This relational ethic is evident when researchers recognise when they are guests (hopefully invited guests) contributing to knowledge about places Indigenous peoples are related to (see Blackett et al. (2021) for more specific details about this approach).

\footnotetext{
${ }^{37}$ Revision of Aotearoa New Zealand's Resource Management Act may enable this however those leading the process of change will need to draw on robust social science insights to enable navigation of the power asymmetries the scholars referenced in this paper have identified which currently shape environmental politics in Aotearoa New Zealand.
} 
Table 2 Methodological sensitivities for co-producing knowledge through enduring trustful partnerships

\begin{tabular}{|c|c|}
\hline Signs to help navigate knowledge co-production journeys & Why: impacts on ways of knowing and doing environments \\
\hline Alternative worlds are becoming visible and possible & $\begin{array}{l}\text { Respectfully including new and marginalised actors enables framing for } \\
\text { a plurality of worlds }\end{array}$ \\
\hline Power asymmetries are being made visible & $\begin{array}{l}\text { Naming who is able to define agenda, short list choices in decision } \\
\text { pathways, gate keeps investment allocations, gives a robust basis for } \\
\text { dialogue }\end{array}$ \\
\hline $\begin{array}{l}\text { Invitations from Indigenous peoples are accepted, and challenges are } \\
\text { being responded to }\end{array}$ & $\begin{array}{l}\text { Constructive and consistent responses to invitations are candid and } \\
\text { reflexive responses to identified inadequacies of interpretations and } \\
\text { behaviour helps grow respect and trust }\end{array}$ \\
\hline $\begin{array}{l}\text { Indigenous ways of representing non-Indigenous people are at the } \\
\text { centre }\end{array}$ & $\begin{array}{l}\text { Efforts aimed at 'centering' or foregrounding' propositions in use by } \\
\text { Indigenous peoples' are a reassuring step in co-creating new kinds and } \\
\text { styles of knowledge }\end{array}$ \\
\hline The stumbling, failures and mistakes are acknowledged and redressed & $\begin{array}{l}\text { Candid listing of and admission of behavioural and representational } \\
\text { transgressions (as seen by others) allows the re-crafting of more con- } \\
\text { siderate contributions }\end{array}$ \\
\hline Care is taken when moving insights from one context to another & $\begin{array}{l}\text { That management happens in place, values are derivative of place-based } \\
\text { social processes and care happens in place, should be a sufficient } \\
\text { social warning that attempts to generalise into other contexts could be } \\
\text { an affront to those in other places and those whose deliberations have } \\
\text { been framed for wider scrutiny }\end{array}$ \\
\hline Shared leadership is remaking institutional spaces & $\begin{array}{l}\text { Transitioning into shared leadership modes confronts the multiple } \\
\text { politics and power relations of existing institutional arrangements and } \\
\text { introduces previously unavailable capacities to support collectively } \\
\text { oriented efforts }\end{array}$ \\
\hline Shared values are explored for points of connection & $\begin{array}{l}\text { Co-listening to the stated values of others is a first step in identifying } \\
\text { and negotiating connections and their potentialities }\end{array}$ \\
\hline Relationship building is prioritised & $\begin{array}{l}\text { Relationships are fueled by connections, while networking draws on } \\
\text { relationships, together they are foundational for forming situated and } \\
\text { wider futures }\end{array}$ \\
\hline
\end{tabular}

Here, we present this work of intentional positioning, representation and reflexivity ${ }^{38}$ as methodological sensitivities. This notion is helpful because its draws attention to both the affective aspects (sensitivity as empathy) and the material (sensitivity as gentle touch). The term methodological sensitivities invites an embodied collective responsiveness by researchers and their collaborators (and funders) to the knowledge systems, situations, aspirations, challenges, and invitations of Indigenous peoples - just as to jib a yacht is a situated response not only to technical understanding of motion but also to a sensitivity to the wind on the face, the swell against the bow, the skills and comportment of those on board the yacht, and the physical effort required.

Table 2 is a resource developed from the interviews, workshops and co-analysis to prompt co-learning across cohorts of research practitioners about how methodologies are sensitised. We imagine this table being used in both review and planning phases of research, guiding capability development for research collaborations. It will need

\footnotetext{
${ }^{38}$ Critical reflexivity works with understandings of power, agency and politics enacted through discourse, practices, and knowledge representations. It is knowingly performative (see Thrift 2004).
}

refining for each context. This table was initially developed by Alison, Richard and Erena, based on review of the discussions Gradon, Alison and Holden had participated in at the December 2020 workshop. Further development of the table occurred as the paper was being written, literatures read and re-read, and the wider group of authors considered the signs in relation to other initiatives they were involved with (for example Kirk et al. (2021).

This resource supports environmental research practitioners moving towards an unknown and as yet unknowable knowledge destination, solution or outcome. It may also help groups move beyond the paralysis ${ }^{39}$ generated when nonIndigenous partners become cognisant of the enormity of devastation their Indigenous partners are working through (Hotere-Barnes 2015). Furthermore, we are contributing to the conversation in Aotearoa New Zealand about how we can know we are building enduring trustful partnerships.

Future research will extend support to groups involved with fresh water and coastal management as they learn to be manuhiri. When an Indigenous relational frame becomes

\footnotetext{
39 This video (https://www.youtube.com/watch?v=G-cAK3YwDUY) provides a great resource to further explore the idea of Pākehā paralysis.
} 
the focus of attention, the possibilities generated for people and nature include alternative ways of connecting and generative networking. Learning to be responsible manuhiri is an opportunity to co-produce collective care for and with nature. Is it possible to avoid co-opting the manuhiri framing as responses are developed to the invitation for revitalised relationships that it proposes? This requires ongoing consideration.

\section{Conclusion}

Several major developments in Aotearoa New Zealand have intersected to make this paper possible. These intersections have given new purpose and content to knowledge co-production encounters for sustainability, and the co-production of sustainability science. As Aotearoa New Zealand's Department of Conservation withdrew from conventional management of Te Urewera, there was a gathering momentum internationally to hear the voice of rivers, forests, and lakes. Now legislation enshrines and empowers this for $\mathrm{Te}$ Urewera and Ngāi Tūhoe have responded to the gravity of all that is now visible through the Department of Conservation's reimagining of its relationship with Te Urewera. In their response they have gifted alternative and generous revisioning's of how people and nature care for each other. Also signalling how researchers and practitioners might arrive more justly and sustainably in places through encounters with Indigenous peoples and their knowledge systems. There is now increased willingness through Aotearoa New Zealand's National Science Challenges to support initiatives that blend mātauranga and critical social science. This responds to and enables the personal odysseys of our contributing authors. We are now more able to actively engage in transdisciplinary conversations and establish new methodological sensitivities.

The paper is knowingly positioned in these grounded preconditions. Its focus is on an emergent set of inter-fusing initiatives around the problematic of how non-Indigenous knowledge systems support Indigenous peoples' approaches to cultural and environmental management. These initiatives have been set in motion by synergistic interplays of the changing conditions facing and circumstances of environment-oriented actors in and beyond Aotearoa New Zealand.

The paper sketches elements of the social processes that have destabilised and yet also restabilised the content and potency of manuhiri in principle and practice, acknowledging it is a living concept about which much is still to be known. Different knowledge challenges are made possible by provoking reassessment of existing methodologies and the visioning and exploration of new methodological emphases and sensitivities.

This 'arrival' of manuhiri (in its mobile and mutable forms) presses further questions, such as: how might further mātauranga and critical social science encounters be enabled and what new connections are accompanying this social object-manuhiri? Who will be enfolded into or left out as researchers and practitioners develop methodological sensitivities and re-learn together? This is a knowledge challenge and transformation opportunity we hope to see the IPBES take up as they deepen their commitments to coproducing environment-oriented knowledge and practices with Indigenous knowledge systems.

\section{Glossary (informed by www. maoridictionary.co.nz)}

Hapū

Iwi

Kaimanaaki

Kairangahau Māori

Kaupapa Māori

Kauri

Mana motuhake

Marae

Mātauranga

Ngāi Tūhoe

Rāhui
Local sub-tribes that make up larger iwi groupings, at local or district geographic level

An extended kinship group, tribe, nation, people, nationality, raceoften refers to a large group of people descended from a common ancestor and associated with a distinct territory

Those who provide care

Māori researchers

Māori approach, Māori topic, Māori customary practice, Māori institution, Māori agenda, Māori principles, Māori ideology: a philosophical doctrine, incorporating the knowledge, skills, attitudes and values of Māori society

Agathis australis

Self-determination

Gathering space, courtyard-the open area in front of the wharenui, where formal greetings and discussions take place

Māori knowledge, Māori knowledge system, belief system, wisdom

An extended kinship group relating to the Te Urewera region in the Bay of Plenty of Aotearoa New Zealand

To put in place a temporary ritual prohibition, closed season, ban, reserve-traditionally, a rāhui was placed on an area, resource or 
stretch of water as a conservation measure or as a means of social and political control for a variety of reasons which can be grouped into three main categories: pollution by tapu, conservation and politics

Rūnanga or Rūnaka

Tangata tiriti

Tangata whenua

Te ao Māori

Te Kawa o Te Urewera

Te Mana o te Wai

Te Tiriti o Waitangi/

the Treaty of Waitangi Is one of Aotearoa New Zealand's founding documents, establishing rights, responsibilities, and relationships between the Crown and tangata whenua. It takes its name from the place in the Bay of Islands where it was first signed, on 6 February 1840

Te Uru Taumatua

A governing body which leads and serves the cultural permanency and prosperity of Ngāi Tūhoe

Whakapapa

Wai

Whaitua

Whenua
Acknowledgements We acknowledge Te Urewera and Ngāi Tūhoe iwi for the invitation for friendship and the opportunity to become manuhiri. This work was made possible by the generous contributions of time, good will and insight by all who participated in the interviews, workshops and collegial conversations informing this paper. Carl Chenery's advisory support to Alison Greenaway was also formative. Funding was received from Te Uru Taumatua (Ngāi Tūhoe Iwi), Manaaki Whenua-Landcare Research, and the Ministry of Business, Innovation and Employment through the Mobilising for Action theme of the Biological Heritage National Science Challenge, Ngā Rākau Taketake Programme. Anne Austin provided editing support. Finally, we offer great thanks to the reviewers of this paper. Their generous and constructive reviews have contributed enormously to refining this paper and helping us communicate with the ethic of care we were seeking.

Author contributions AG conceived of and designed the study. AG and $\mathrm{HH}$ undertook fieldwork in Te Urewera and in Wellington with Gradon Diprose. Material preparation, additional data collection, and analysis were performed by all authors. The first draft of the manuscript was written by AG and all authors commented on previous versions of the manuscript. All authors read and approved the final manuscript.

\section{Declarations}

Conflict of interest The authors have no relevant financial or non-financial interests to disclose.

Open Access This article is licensed under a Creative Commons Attribution 4.0 International License, which permits use, sharing, adaptation, distribution and reproduction in any medium or format, as long as you give appropriate credit to the original author(s) and the source, provide a link to the Creative Commons licence, and indicate if changes were made. The images or other third party material in this article are included in the article's Creative Commons licence, unless indicated otherwise in a credit line to the material. If material is not included in the article's Creative Commons licence and your intended use is not permitted by statutory regulation or exceeds the permitted use, you will need to obtain permission directly from the copyright holder. To view a copy of this licence, visit http://creativecommons.org/licenses/by/4.0/.

\section{References}

Allen W, Ataria JM, Apgar JM, Harmsworth G, Tremblay LA (2009) Kia pono te mahi putaiao-doing science in the right spirit. J R Soc NZ. https://doi.org/10.1080/03014220909510588

Allen W, Ogilvie S, Blackie H, Smith D, Sam S, Doherty J, Eason C (2014) Bridging disciplines, knowledge systems and cultures in pest management. Environ Manag 53(2):429-440. https://doi.org/ 10.1007/s00267-013-0180-z

Apgar JM, Allen W, Albert J, Douthwaite B, Paz Ybarnegaray R, Lunda J (2017) Getting beneath the surface in program planning, monitoring and evaluation: learning from use of participatory action research and theory of change in the CGIAR Research Program on Aquatic Agricultural Systems. Action Res 15(1):15-34

Australian Research Council (2020) Outcomes paper: Australian and New Zealand standard research classification review 2019. Australian Research Council

Athayde S, Silva-Lugo J, Schmink M, Kaiabi A, Heckenberger M (2017) Reconnecting art and science for sustainability: learning from indigenous knowledge through participatory 
action-research in the Amazon. Ecol Soc. https://doi.org/10.5751/ ES-09323-220236

Bataille C, Luke K, Kruger T, Malinen S, Allen R, Whitehead A, Lyver POB (2020) Stakeholder values inform indigenous peoples' governance and management of a former National Park in New Zealand. Hum Ecol 48(4):439-453

Blackett P, FitzHerbert S, Luttrell J, Hopmans T, Lawrence H, Colliar J (2021) Marae-opoly: supporting localised Māori climate adaptation decisions with serious games in Aotearoa New Zealand. Sustain Sci. https://doi.org/10.1007/s11625-021-00998-9

Bolger D (2019) Mayor blasted over 'wrong and abusive process'. Star News 4th September.

Borell B, Waru Rewiri KT, Barnes HM, McCreanor T (2019) Beyond the veil: Kaupapa Māori gaze on the non-Māori subject. J Sociol 56(2):197-212. https://doi.org/10.1177/1440783319893503

Brookes A (2018) School and youth group camp and excursion catastrophic events on land: lessons for prevention. In: Preventing fatal incidents in school and youth group camps and excursions (pp. 101-125): Springer.

Came-Friar H, McCreanor T, Manson L, Nuku K (2019) Upholding Te Tiriti, ending institutional racism and Crown inaction on health equity. N Z Med J 132(1492):62-66

Carolan M (2009) 'I do therefore there is': enlivening socio-environmental theory. Environ Politics 18(1):1-17

Chilisa B (2017) Decolonising transdisciplinary research approaches: an African perspective for enhancing knowledge integration in sustainability science. Sustain Sci 12(5):813-827

Chitondo M, Dombroski K (2019) Returning water data to communities in Ndola, Zambia: a case study in decolonising environmental science. Case Stud Environ. https://doi.org/10.1525/ cse.2018.001552

de Sousa Santos B (2008) Another knowledge is possible: beyond northern epistemologies. Verso

Duncan R, Robson-Williams M, Nicholas G, Turner JA, Smith R, Diprose D (2018) Transformation is 'experienced, not delivered': insights from grounding the discourse in practice to inform policy and theory. Sustainability 10(9):3177. https:// doi.org/10.3390/su10093177

Elkington B, Jackson M, Kiddle R, Mercier O, Ross M, Smeaton J, Thomas A (2020) Imagining decolonisation. Bridget Williams Books, Wellington

Forsyth H (2018) An identity as Pākehā. AlterNative Int J Indig Peoples 14(1):73-80

Garnett ST, Burgess ND, Fa JE et al (2018) A spatial overview of the global importance of Indigenous lands for conservation. Nat Sustain 1:369-374. https://doi.org/10.1038/s41893-018-0100-6

Geddis A, Ruru J (2019) Places as persons: creating a new framework for Māori-Crown relations. In: The frontiers of public law. Hart Publishing, London.

Greenaway A (2020) Friendship for (and with) Te Urewera: insights from interviews in 2019. A Manaaki Whenua-Landcare Research Contract Report (LC3672) prepared for Te Uru Taumatua, Ngāi Tūhoe Iwi

Harmsworth GR, Awatere S (2013) Indigenous Māori knowledge and perspectives of ecosystems. Ecosystem services in New Zealand-conditions and trends. Manaaki Whenua Press, Lincoln, New Zealand, 274-286

Harmsworth G, Awatere S, Robb M (2016) Indigenous Māori values and perspectives to inform freshwater management in AotearoaNew Zealand. Ecol Soc 21(4). www.jstor.org/stable/26269997

Hikuroa D, Slade A, Gravley D (2011) Implementing Māori indigenous knowledge (mâtauranga) in a scientific paradigm: restoring the mauri to Te Kete Poutama. MAI Rev 3(1):9

Hill R, Adem Ç, Alangui WV, Molnár Z, Aumeeruddy-Thomas Y, Bridgewater P, Tengö M, Thaman R, Yao CYA, Berkes F, Carino J (2020) Working with indigenous, local and scientific knowledge in assessments of nature and nature's linkages with people. Curr Opin Environ Sustain 43:8-20. https://doi.org/10.1016/j.cosust. 2019.12.006

Hotere-Barnes A (2015) Generating 'non-stupid optimism': addressing Pākehā paralysis in Māori educational research. N Z J Educ Stud 50(1):39-53

Howitt R (2020) Unsettling the taken (for granted). Prog Hum Geogr 44(2):193-215

Huygens I (2016) Pākehā and Tauiwi Treaty education: an unrecognised decolonisation movement? Kōtuitui N Z J Soc Sci Online 11(2):146-158

Jasanoff S (2004) States of knowledge: the co-production of science and the social order. Routledge, Milton Park

Johnson JT, Howitt R, Cajete G et al (2016) Weaving indigenous and sustainability sciences to diversify our methods. Sustain Sci 11:111. https://doi.org/10.1007/s11625-015-0349-x

Jones C (2014) Tūhoe-Crown settlement-Tūhoe Claims Settlement Act 2014; Te Urewera report of the Waitangi Tribunal. Māori Law Rev, 13-15

King DNT, Skipper A, Tawhai WB (2008) Māori environmental knowledge of local weather and climate change in Aotearoa-New Zealand. Clim Change 90(4):385-409

Kirk NA, Harcourt N, Greenaway A, Robson-Williams M (2021) Methodological sensitivities for non-indigenous researchers adopting indigenous research methods for online data collection. International Transdisciplinarity Conference. Bern: Schweiz

Kluttz J, Walker J, Walter P (2020) Unsettling allyship, unlearning and learning towards decolonising solidarity. Stud Educ Adults 52(1):49-66. https://doi.org/10.1080/02660830.2019.1654591

Lambert S, Waipara N, Black A, Mark-Shadbolt M, Wood W (2018) Indigenous biosecurity: Māori responses to kauri dieback and myrtle rust in Aotearoa New Zealand. In: The human dimensions of forest and tree health, Springer, Berlin, pp 109-137

Latulippe N, Klenk N (2020) Making room and moving over: knowledge co-production, Indigenous knowledge sovereignty and the politics of global environmental change decision-making. Curr Opin Environ Sustain 42:7-14. https://doi.org/10.1016/j.cosust. 2019.10.010

Le Heron E, Logie J, Allen W, Le Heron R, Blackett P, Davies K et al (2019) Diversity, contestation, participation in Aotearoa New Zealand's multi-use/user marine spaces. Mar Policy 106:103536

Le Heron E, Le Heron R, Logie J, Greenaway A, Allen W, Blackett $\mathrm{P}$, et al (2020a) Participatory processes as twenty-first-century social knowledge technology. Sustain Seas Ocean Space Politics Care, 155

Le Heron E, Le Heron R, Taylor L, Lundquist CJ, Greenaway A (2020b) Remaking ocean governance in Aotearoa New Zealand through boundary-crossing narratives about ecosystem-based management. Mar Policy 122:104222. https://doi.org/10.1016/j. marpol.2020.104222

Le Heron E, Allen W, Le Heron R, Logie M, Glavovic B, Greenaway A et al (2021) What does success look like? An indicative rubric to assess and guide the performance of marine participatory processes. Ecol Soc 26(1)

Lomax AJ (2015) A tangled web: the complex relationships of governance and management in the Te Waihora catchment. Lincoln Plann Rev 7(1-2):48-49

Lyver POB, Richardson SJ, Gormley AM, Timoti P, Jones CJ, Tahi BL (2018) Complementarity of indigenous and western scientific approaches for monitoring forest state. Ecol Appl 28(7):1909-1923

Maclean K, Woodward E, Jarvis D, Turpin G, Rowland D, Rist P (2021) Decolonising knowledge co-production: examining the role of positionality and partnerships to support Indigenousled bush product enterprises in northern Australia. Sustain Sci. https://doi.org/10.1007/s11625-021-00973-4 
Magallanes CJI (2015) Nature as an ancestor: two examples of legal personality for nature in New Zealand. VertigO Revue Électronique En Sciences De L'environnement. https://doi.org/10.4000/ vertigo. 16199

Maxwell K, Awatere S, Ratana K, Davies K, Taiapa C (2020) He waka eke noa/we are all in the same boat: a framework for co-governance from aotearoa New Zealand. Mar Policy 121:104213

McAllister TG, Naepi S, Wilson E, Hikuroa D, Walker LA (2020) Under-represented and overlooked: Māori and Pasifika scientists in Aotearoa New Zealand's universities and crown-research institutes. J R Soc N Z. https://doi.org/10.1080/03036758.2020. 1796103

Mead HM (2016) Tikanga Māori (revised edition): Living by Māori values. Huia Publishers, Wellington

MfE (2020) National Policy Statement for Freshwater Management. Ministry for the Environment. https://environment.govt.nz/ publications/national-policy-statement-for-freshwater-manag ement-2020/

Mikaere A (2011) Colonising myths-Māori realities: He rukuruku whakaaro: Huia Publishers, Wellington

Moewaka Barnes H, Harmsworth G, Tipa G, Henwood W, McCreanor T (2021) Indigenous-led environmental research in Aotearoa New Zealand: beyond a transdisciplinary model for best practice, empowerment and action. AlterNative Int J Indig Peoples 11771801211019397

New Zealand Government (2021) Teaching NZ's own history moves a step closer. Press release from Beehive.govt.nz February 3rd

Norström AV, Cvitanovic C, Löf MF, West S, Wyborn C, Balvanera P, Österblom H (2020) Principles for knowledge co-production in sustainability research. Nat Sustain 3(3):182-190

Parsons M, Fisher K (2020) Indigenous peoples and transformations in freshwater governance and management. Curr Opin Environ Sustain 44:124-139. https://doi.org/10.1016/j.cosust.2020.03.006

Parsons M, Taylor L, Crease RJS (2021) Indigenous environmental justice within marine ecosystems: a systematic review of the literature on indigenous peoples' involvement in marine governance and management. Sustainability 13(8):4217. https://doi.org/ $10.3390 / \mathrm{su} 13084217$

Rata A, Hutchings J, Liu JH (2012) The Waka Hourua Research Framework: a dynamic approach to research with urban Māori communities. Aust Commun Psychol 24(1)

Reo NJ, Whyte KP, McGregor D, Smith MA, Jenkins JF (2017) Factors that support Indigenous involvement in multi-actor environmental stewardship. AlterNative Int J Indig Peoples 13(2):58-68. https:// doi.org/10.1177/1177180117701028

Robb M, Harmsworth G, Awatere S (2015) Māori values and perspectives to inform collaborative processes and planning for freshwater management. Landcare Research contract Report No. LC2119. $66 \mathrm{p}$

Rout M, Reid J (2020) Embracing indigenous metaphors: a new/old way of thinking about sustainability. Sustain Sci 15(3):945-954. https://doi.org/10.1007/s11625-020-00783-0
Ruru J (2004) Managing our treasured home: the conservation estate and the principles of the Treaty of Waitangi. NZJ Envtl L 8:243

Ruru J, O'Lyver PB, Scott N, Edmunds D (2017) Reversing the decline in New Zealand's biodiversity: empowering Māori within reformed conservation law. Policy Q. https://doi.org/10.26686/ pq.v13i2.4657

Ruru J, Nikora LW (2021) Ngā Kete Mātauranga. Māori scholars at the research interface, Otago University Press, Dunedin

Said E (1978) Orientalism: Western concepts of the Orient. Pantheon, New York

Seehawer MK (2018) Decolonising research in a Sub-Saharan African context: exploring Ubuntu as a foundation for research methodology, ethics and agenda. Int J Soc Res Methodol 21(4):453-466

Selak V, Rahiri J-L, Jackson R, Harwood M (2020) Acknowledging and acting on racism in the health sector in Aotearoa New Zealand. N Z Med J 133

Shiva V (2001) Monocultures of the Mind. Creative management and development. Sage, Thousand Oaks

Smith LT (1999) Decolonising methodologies: researching and indigenous peoples. University of Otago Press, Dunedin

Stevens M (2020) Stuff's apology to Māori-our truth, Tā Mātou Pono. Stuff Editorial. Nov 30th

Te Uru Taumatua (2017) Te Kawa o Te Urewera. www.ngaituhoe.iwi. nz/Te-Kawa-o-Te-Urewera

Taylor L, Te Whenua T, Hatami B (2018) Discussion paper: how current legislative frameworks enable customary management and ecosystem-based management in Aotearoa New Zealand-the contemporary practice of rāhui. Sustainable Seas National Science Challenge

Thrift N (2004) Performance and performativity: a geography of unknown lands. In: A companion to cultural geography (1995), pp 121-36

Timoti P, Lyver POB, Matamua R, Jones CJ, Tahi BL (2017) A representation of a Tuawhenua worldview guides environmental conservation. Ecol Soc. https://doi.org/10.5751/ES-09768-220420

Zanotti L, Palomino-Schalscha M (2016) Taking different ways of knowing seriously: cross-cultural work as translations and multiplicity. Sustain Sci 11(1):139-152. https://doi.org/10.1007/ s11625-015-0312-x

Zurba M, Petriello MA, Madge C, McCarney P, Bishop B, McBeth $S$ et al (2021) Learning from knowledge co-production research and practice in the twenty-first century: global lessons and what they mean for collaborative research in Nunatsiavut. Sustain Sci. https://doi.org/10.1007/s11625-021-00996-x

Publisher's Note Springer Nature remains neutral with regard to jurisdictional claims in published maps and institutional affiliations. 